DOI https://doi.org/10.30525/978-9934-588-79-2-2.21

\title{
ГІДРОЛІЗ ІНУЛІНУ ЕЛЕКТРОІМПУЛЬСНИМ МЕТОДОМ
}

\author{
Попова I. B. \\ доктор філософських наук, кандидат технічних наук, \\ професор кафедри харчової хімї \\ Національного університету харчових технологій \\ Майборода О. I. \\ кандидат хімічних наук, дочент кафедри харчової хімії \\ Національного університету харчових технологій \\ м. Київ, Україна
}

На сучасному ринку харчових продуктів актуальним $є$ розроблення продуктів лікувально-профілактичного призначення на основі місцевої рослинної сировини, зокрема з високим вмістом полісахариду інуліну. Важливим напрямом таких розробок $\epsilon$ промислове перероблення цикорію, багатого на велику кількість цінних біологічно активних сполук протекторної та пребіотичної дії - 3 метою добування фруктозо-олігосахаридних сиропів для подальшого застосування у виробництві продукції оздоровчого харчування.

При здійсненні найбільш розповсюдженого способу гідролізу інуліну, а саме обробкою його розчинів мінеральною кислотою при нагріванні, продукти гідролізу - фруктоза та олігосахариди нижчого степеню полімеризації, ніж інулін, тобто інулоолігосахариди, забруднені, як правило, продуктами дегідратації, розкладу, наступної конденсації фруктози та утворюваними в результаті побічних процесів забарвленими речовинами [1, с. 303-308].

Використання електроімпульсного оброблення для здійснення гідролізу інуліну забезпечує нейтральну реакцію вихідного реакційоного середовища, відсутність домішок інших хімічних агентів, а саме й чистоту утворюваних фруктозо-олігосахаридних сумішей порівняно 3 традиційними способами гідролізу.

Гідроліз за допомогою електроімпульсної обробки здійснювали таким чином: інулін розводили у воді при кімнатній температурі до вмісту сухих речовин у розчині або суспензії від 2 до $30 \%$. У разі приготування суспензії іiі добре перемішували. Порошки для приготування суспензій попередньо замочували у воді на 72 години для набухання зерен полісахариду, що в подальшому сприяло найповнішому гідролізу зразків. Приготовлений розчин або суспензію піддавали електроімпуль- 
сному обробленню при напрузі $35-40$ кВ із застосуванням від 5 до 75 високовольтних імпульсних розрядів. Після оброблення одержаний розчин був готовий до безпосереднього подальшого застосування.

За рахунок електрогідравлічного ефекту та інших фізичних явищ, які виникають під час високовольтного розряду у рідині, відбувається механічний розрив молекул інуліну по місцю глікозидних зв'язків між фруктозними структурними одиницями с подальшим приєднанням молекули води, тобто частковий гідроліз молекул інуліну. При цьому деяка частина молекул інуліну перетворюється в кінцевий продукт повного гідролізу - фруктозу. Ефект гідролізу досягається у нейтральному середовищі, без додавання будь-яких хімічних реагентів і не супроводжується утворенням забарвлених побічних продуктів.

Вміст сухих речовин $(\mathrm{CP})$ у реакційній суміші визначали рефрактометричним методом, а для контролю вмісту фруктози в гідролізаті використовували класичний метод Мюллера для визначення редукуючих речовин [2, с. 122].

Для встановлення оптимальних режимів електроімпульсної обробки вивчали залежність вмісту редукуючих речовин у продуктах оброблення (гідролізатах) від кількості високовольтних розрядів за умови різних концентрацій досліджуваних розчинів або суспензій та особливостей їх підготовки.

Можна запропонувати таке пояснення оптимальної дії електроімпульсних розрядів на препарати інуліну та цикорію. Відомо, що інулін $\epsilon$ сполукою малостійкою до механічних впливів, тому його молекули руйнуються (фрагментуються) навіть при прикладанні механічних зусиль, наприклад при стиранні. Ударна хвиля, що виникає при електричному пробої середовища внаслідок високовольтного іскрового розряду, спричинює, перш за все, механічний вплив на молекулу інуліну. Така хвиля інтенсивно перемішує систему, створюючи розтягуючі зусилля в рідині і виклакає утворення кавітаційних порожнин, які сприяють диспергуванню частинок [3, с. 113-115].

Зі збільшенням кількості імпульсних зарядів збільшується дисперсність оброблюваного матеріалу за рахунок фрагментації молекул інуліну внаслідок його гідролізу за таких умов.

Вірогідно, що зростання кількості імпульсів вище оптимального значення створює умови для рекомбінаційних процесів, при яких утворені на перших етапах гідролізу молекули D-фруктози в термодинамічно відносно малостійкій $\beta$-фуранозній формі не перетворюються в термодинамічно стійкішу $\beta$-піранозну форму (як це відбувається за умов звичайного гідролізу - без застосування електроімпульсної обробки), а взаємодіють одне з одним, утворюючи димери, тримери, 86 
тетрамери та інші фруктани меншого ступеню полімеризації, ніж інулін, тобто інулоолігосахариди.

У таблиці 1 наведені приклади деяких дослідів, в яких були встановлені параметри електроіскрової обробки розчинів і суспензій інуліну.

Дослідження впливу електроіскрових високовольтних розрядів на водні суспензії порошків сушеного та обсмаженого цикорію показали, що для препаратів цикорію зберігається та сама тенденція, що і для інуліну, а саме: за оптимальної напруги 35-40 кВ збільшення кількості імпульсів, прикладених до зразку суспензії, приводить до підвищення вмісту редукуючих речовин до максимального значення при 25-30 імпульсах, а потім зменшується за рахунок рекомбінаційних процесів.

У зразках суспензій цикорних порошків, крім того, одночасно 3 гідролізом інуліну відбувається гідроліз білкових сполук до амінокислот, що при кількості імпульсів 75 і вище приводить до розкладу амінокислот з утворенням аміаку та нижчих амінів.

Таблиця 1

Визначення режимів електроімпульсного оброблення водних розчинів та суспензій інуліну

\begin{tabular}{|c|c|c|c|c|c|}
\hline $\begin{array}{c}\text { Напру- } \\
\text { га, кB }\end{array}$ & $\begin{array}{c}\text { Кіль- } \\
\text { кість } \\
\text { імпуль- } \\
\text { сів }\end{array}$ & $\begin{array}{c}\text { Вміст } \\
\text { СP, } \\
\text { \% }\end{array}$ & $\begin{array}{c}\text { Вміст } \\
\text { фруктози } \\
\text { в одер- } \\
\text { жаній } \\
\text { суміші,\% }\end{array}$ & $\begin{array}{c}\text { Ступінь } \\
\text { гід- } \\
\text { ролізу,\% }\end{array}$ & Висновки \\
\hline 35 & 5 & 20,1 & 21,6 & 22,1 & $\begin{array}{c}\text { Недостатня кількість ім- } \\
\text { пульсів для процесу гід- } \\
\text { ролізу інуліну }\end{array}$ \\
\hline 40 & 10 & 20,5 & 14,69 & 48,6 & $\begin{array}{c}\text { Вміст редукуючих речовин } \\
\text { в одержаний суміші зростає }\end{array}$ \\
\hline 35 & 20 & 20,7 & 25,94 & 53,9 & $\begin{array}{c}\text { Достатня кількість імпуль- } \\
\text { сів для процесу часткового } \\
\text { гідролізу інуліну }\end{array}$ \\
\hline 35 & 25 & 22 & 30,5 & 55,4 & $\begin{array}{c}\text { Оптимальний режим для } \\
\text { утворення фруктозо- } \\
\text { олігосахаридної суміші }\end{array}$ \\
\hline 35 & 75 & 22,1 & 29,5 & $\begin{array}{c}\text { Вміст едукуючи речовин } \\
\text { зменшується, а ступінь } \\
\text { полімеризації інулоолігоса- } \\
\text { харидів зростає }\end{array}$ \\
\hline & 50 & 15,5 & 44,5 & $\begin{array}{c}\text { Ступінь полімеризації } \\
\text { інулоолігосахаридів ще } \\
\text { зростає за рахунок реком- } \\
\text { бінаційних процесів, збіль- } \\
\text { шення кількості імпульсів } \\
\text { недоцільне }\end{array}$ \\
\hline
\end{tabular}




\section{Література:}

1. De Bruyn A., Alvarez A.P., Sandra P., De Leenheer L. O- $\beta$-Dfructofuranosyl-( $2 \rightarrow 1)$-O- $\beta$-D-fructofuranosyl-( $2 \rightarrow 1)$-D-fructose, a product of the enzymic hydrolysis of the inulin from Cichorium intybus // Carbohydr. Res.-1992.-Vol.235.

2. C.Е. Траубенберг, Пищевая химия (Углеводы, минеральные вещества, вода). / Траубенберг С.Е., Осташенкова Н.В., Вяльцева И.В., Кобелева И.Б. и др. - М. : Изд.комплекс МГУПП, 2003.

3. Вагабов М.В., Мангуева 3.М., Мурзаева П.Д. Оптимизация ферментативного процесса гидролиза инулина из топинамбура. // Вестник ДГТУ. - 2007. - № 12.

DOI https://doi.org/10.30525/978-9934-588-79-2-2.22

\section{ДОСЛІДЖЕННЯ СПОСОБІВ КОРЕКЦІЇ СЕЛЕНОДЕФІЦИТНИХ СТАНІВ ЛЮДИНИ}

Применко В. Г.

кандидат технічних наук,

завідувач кафедри менеджменту і адміністрування

Відокремленого підрозділу "Дніпровський факультет менеджменту

і бізнесу Київського університету культури»

Сефіханова К. А.

кандидат технічних наук,

декан

Відокремленого підрозділу "Дніпровський факультет менеджменту

i бізнесу Київького університету культури»

Щеньова В. Б.

кандидат технічних наук,

дочент кафедри менеджменту і адміністрування

Відокремленого підрозділу "Дніпровський факультет менеджменту

i бізнесу Київького університету культури»

$$
\text { м. Дніпро, Україна }
$$

Значний розвиток хімічної та харчової промисловостей спонукав до виникнення індустрії дієтичних добавок з метою збагачення продуктів на вітаміни, мінеральні речовини та інші харчові компоненти. Так, введення до складу добавок амінокислотних комплексів із селе88 